\title{
Subjective Welfarism, Communitarian Paternalism and the Aristotelian Quest for the Good Society
}

\author{
*Adeshina Afolayan and Francis Offor \\ http://dx.doi.org/10.4314/ujah.v15i1.3
}

\section{Abstract}

In this essay, we examine the philosophical debate between advocates of liberal welfarism and communitarian paternalism on the role of the individual and the state in actualising the Aristotelian quest for the good society. The paternalistic implications of a state imposing a general conception of the good on individuals' personal and subjective inclinations were examined, against the welfarist's exaltation of the private preferences of individual citizens as the only justifiable platform for the legitimacy of government decisions, legislations and policies. While admitting with the subjective welfarists that each individual has his/her own autonomous vision of a good society and the good life, the essay contends that such autonomy can only be formulated within the ambit of state protectionism and that this provides the basis for government's regulation and intervention in the processes of preference formation. Resolving the controversy between subjective welfarism and communitarian paternalism on the role of the individual and the state, in the quest for the good life and the good society would, the essay concludes, require more empirical arguments than what both the subjective liberal welfarists and the communitarian paternalists have so far felt disposed to provide. 
Key Words: Ethics, Politics, The good society, Paternalism, Subjective welfarism,

\section{Introduction}

One of the major challenges Aristotle sought to address was how to evolve the good society conducive for the realisation of individuals' self-fulfillment. However, the path-way to the good society is for many, to be charted by politics, given the centrality of politics in providing direction for the overall effective performance of other sectors of society. But for politics to achieve this feat, it must parlay morality, for there is always a grievous danger in any art of politics outstripping morality (Omoregbe, 1991: 117). For instance, separating morality from politics would have implications for law, whose validity depends by its very nature, on the fulfilling of certain moral conditions (Fuller, 1958: 631), and the life of reason which actuates the good society is only possible under the rule of law. In this wise, morality becomes essential not only for society's preservation but also for the survival of individuals within it.

In this essay, we examine the polemics generated by the joint attempt by ethics and politics to craft a good and virtuous society, and the ensuing acute philosophical debate between the advocates of liberal welfarism and communitarian paternalism on the role of the individual and the state in the quest for the good society. But first, let us start our discussion by exploring the nexus between ethics, politics and the Aristetolian imperative for the good society. 


\section{Crafting a Good Society: The Nexus between Ethics and Politics}

The society matters; and more so is the political community. How they matter is however a different consideration for the various individuals who constitute them. This difference is also the beginning of the theorisation of the conflict which the society internalises. The society is thus a spatial matrix of conflict and cooperation (to the extent that it is achieved) in the various hues possible.

The art of politics in this context is a significant intervention in the charged web of free flowing but intense values, perceptions, preferences and ideals that various individuals contributed to the communal pool of interdependence. To do this, politics had to hijack the whole of society and define its web politically. Hinsley is very clear on how politics was able to achieve this definition of society as a political community rather than, say, a theological, social or even economic one. Hinsley's Sovereignty charts the course that led to the consolidation of the theory of rule and dominance intrinsic to the concept of the political community and state sovereignty. As regards its evolution, Hinsley characterises the state as "a distinctive political institution, the particular means of organising political power which societies have adopted at a particular stage in their evolution" (Hinsley, 1989: 3).

The transition from stateless communities to the state system constitutes "a leap or shock" whose impact is lessened by the fact, for Hinsley, that it represents 
human beings' natural ambition to possess the absolute authority exemplified by the central state. This suggests why the transition nevertheless takes place in spite of the reluctance of the transiting societies and the political trauma involved. Once the first step is taken towards the emergence of the state, its growth becomes so enormous that it threatens to overshadow and absorb the entire function of society. This first step involved the state's irreverent attempt to submerge the dividing line between itself and other political institutions of society and the societies themselves.

The irreverence explains a lot! The modern state itself represents the victory of the theory of rule and dominance, and of the idea that there is a final and absolute political authority in the community. Hinsley warns that it does not then follow that wherever the state has emerged, it has been inexorably followed by the concept of sovereignty. The existence of the state, for him, is only a necessary condition for the development and consolidation of the idea of sovereignty. What is further needed, as a sufficient condition, is the eradication of the theoretical boundary between the state and the need of the community. In other words, sovereignty emerges necessarily only when the balance of power, "between the centre and the other wielders of power over whom the centre exercises only limited control has..." (ibid: 19) shifted so much to the centre as to facilitate the replacement of the segmentary units by the unitary state and by a single hierarchical society. 
The theory of rule demands that the state and the society must not only be integrated to a certain extent, but also significantly that the state must impose itself on the society as the instrument of a power that is alien to those natural ways of the society. That is, the psychological and moral coercion which emanates directly from the community is sharply contrasted to the structure of command which the state imposes as a condition of rule. Hinsley traces the trajectory of the historical development which led to this imposition:

The concept of sovereignty originated in the closer association of the developing state and the developing community which became inevitable when it was discovered that power had to be shared between them. The function of the concept was to provide the only formula which could ensure the effective exercise of power once this division of power or collaboration of forces had become inescapable. It was on this account that, to begin with, it placed the sovereignty in the rulership (ibid: 222).

This quotation points, in other words, to the most significant phase in the gradual but inexorable consolidation of the centralised absolutism of the emerging state. This was the growing integration of hitherto segmentary communities under one ruler who was conceived to be above the law and custom of those communities, and who had a new degree of control over the emerging territories.

There may after all be a sense to this trajectory of the consolidation of the state over society. Society and the 
political community is a conflict zone because of the constant antagonism between the self-constituting nature of the human persons and their social, polis-seeking proclivity. If the social contract theorists are to be believed, the allures of our gregarious nature supersede the danger that attends self-constitution. Yet, unknown to Hobbes and others, it is precisely the relative stability of the civil and political society that promotes the yearnings for variations in the constitution of the self against the self-constitution of others and the formality of the General Will. In this sense, to say that it is politics that provides the antidote against the permanent possibility of a return to the anarchy in the state of nature may not really be true as we will see later in the essay.

The etymological synonymity between "policy" and "politics" in Anglo-Saxon thought is not ordinary in spite of any superficial difference involved in their definition. Both are "plans of actions" involving the idea of organising or directing other men

(Aron, 1978: 23). Politics essentially is a policy making activity which, for Aron, reaches "its completion in the search for a regime, that is to say, for the method by which rules of organisation and direction are determined" (Aron, 1978: ibid). Indeed, a commentator has defined politics as the attempt by the few to make general policy decisions for the majority (Shively, 1997: 13). It is in this wise that we may speak of the political regime of MTN, Mr. Biggs, Chevron, as well as that of Lesotho, Japan, Nigeria and the United States. 
As we have noted earlier on, politics attempts to intervene in the web of ideals, perceptions, values, and ultimately in the conflict in the society. To do this, the art of politics must enforce dialogue:

Defined in this way, politics always carries with it an element of dialogue between two poles of constraint and persuasion, of violence and discussion between equals. Politics is dialectics when it unfolds between men who mutually acknowledge each other. It is war when it brings into opposition men who, while acknowledging each other's freedom, wish to remain strangers to one another..." (Aron, 1978: 23).

It is here that we find the raison d'etre for legislations and regulations. In other words, the life of reason which actuates the stability of the state is only possible under the rule of law; possible, that is, when the state "regularise" the behaviours of its human constituents.

However, in order to succeed in building a virtuous society and not just a formal or legal one bereft of vitality, then politics must parlay morality. There is always a grievous danger in any art of politics outstripping morality. Ekeh has just such an incidence in mind when, writing about the famous distinction between the civic public and the primordial public in African politics, he counsels:

Our problem may be partially understood and hopefully solved by the realisation that the civic public and the primordial public are rivals, that in fact the civic public is starved of badly needed morality. Of course, 
"morality" has an old-fashioned ring about it: but any politics without morality is destructive. And the destructive results of African politics in the post-colonial era owe something to the amorality of the civic public (Ekeh, 1975: 111).

We should therefore say that politics' attempt to intervene in the society is only a necessary justification for the commencement of laws and regulations. A sufficient condition derives from ethics' ultimate interrogation of the incidence of politics in the society. This is: how should we make this society a good one? It is from this ethico-political perspective that we think, we can begin to understand our compulsive fascination with the democratic system of government, and the legal framework that grounds its laws and regulations.

For Scott, the significance of ethics in politics is underscored by the fact that "The question of ethics, as experienced, allows us to participate with alertness in the self-overcoming of values and ideals that form our lives and that are structured by often unattended and intense conflicts" (Scott, 1996: 1). Crucially, however, the joint attempt by ethics and politics to craft a good and virtuous society often generates pre-political and preethical excesses which in turn give rise to acute philosophical debates about the nature of the state, society and the role of the individuals in them (we will come to this in the third section of this paper). 


\section{In the Eye of the Storm: The Pre-ethical and Pre- political Considerations}

It is herculean to regulate human behaviours. One reason for this is that power, either ethical or political, excites different emotions in us: it, for instance, inspires pride (and unfortunately arrogance) in those who wield it and instigates fear in those who must bear its imperatives. There is however a limit to which human freedom-our self-constituting nature-can bear the constraints of coercive regulations. Each individual it seems has its own, often pre-political and pre-ethical, visions of a good society and good life project which society should conform with. The raison d'etre of regulative agencies however is either to regulate, restrict or abort such visions for the betterment of the society or the General Will.

Let us reconsider the social contract theorists. Given the Hobbesian and Lockean portrayal of the state of nature, we are given an insight into a probable hypothetical about the emergence and operation of the pre-political and pre-ethical preferences of man in a pre-social circumstance. Hobbes' psychological profile of man in this circumstance is more fascinating than that of Locke. For him, every man, motivated by a self-centred consideration of his preferences, is wont to perceive his relation with others in that skewed perspective. Yet, for both Hobbes and Lock, the motivating justification for the war in the state of nature is liberty - the freedom man has to interpret the law of nature as he deems fit for his self-preservation. Contrary to this minimal application of the principle of individual right to preserve himself, 
Locke counterpoises man's liberty to defend his inalienable rights (to life, liberty and estate) from encroachment by others who possess similar liberty.

Both agreed that such a state of affairs where man constitutes the executor of the laws of nature is not conducive for his own progress. However, their strategy for agreement on a way out of the state of nature radically differs. For Hobbes, the route to an agreement lies through politics. Hobbes' argument is that from the critical juncture of recognising that each has the power to preserve himself, men must recognise that selfpreservation is a good which cannot be preserved within the state of affairs called war. This is the justification for a political arrangement. Thus, to enjoy this right, for Hobbes, men will have to do certain thing: sue for peace. He argues:

For asmuch as all men, carried away by the violence of their passion, and by evil custom, do those things which are commonly said to be against the law of nature; it is not the consent of passion, or consent in some error gotten by custom, that makes the law of nature. Reason is no less of the nature of man than passion, and is the same in all men, because all men agree in the will to be directed and governed in the way to that which they desire to attain, namely their own good, which is the work of reason. There can therefore be no other law of nature than reason, nor no other precepts of natural law, than those which declare unto us the ways of peace, where the same may be obtained, and of defence where it may not. (Hobbes, 1989: I. 15. 1. Emphasis added). 
Locke took a different path to this agreement. The political compulsion of Hobbes gave way to a social voluntariness emanating from man's rational consent. According to Locke,

Wherever, therefore, any number of men so unite into one society as to quit everyone his executive power of the law of Nature, and to resign it to the public, there and there only is a political or civil society. And this is done wherever any number of men, in the state of nature, enter into society to make one people one body politic under one supreme government: or else when any one joins himself to, and incorporates with any government already made. For hereby he authorises the society, or which is all one, the legislative thereof, to make laws for him as the public good of the society shall require, to the execution whereof his own assistance (as to his own decrees) is due (Locke, 1690: VII. 89).

It seems to us that it should be very easy to delineate a path from Hobbes' political explanation of the contract to the contemporary argument for state perfectionism. Locke's theory on its own is the basis for the liberal's adulation of the concept of state neutrality. However, putting aside this considerations for the moment, it is not difficult to surmise, as we noted earlier on, that individuals only camouflaged their natural intends and proclivities when coming into civil or political society.

It stands to reason that the relative stability of the "commonwealth" should provide a perfect atmosphere for the achievement of our personal preferences. This consideration is more conducive to Locke's theory than 
Hobbes. This is because, unlike Hobbes, the Lockean contract is conditional upon the protection of not only the person but also his values and preferences from encroachment by others. For Hobbes, submission to the regulations of the Leviathan derives from men's fear of a return to the anarchy of the state of nature. Thus, their personal interpretation of the good life must be kept under a tight leash and in deference to the state's interpretation of that good.

The fundamental question that seems pertinent in this context is this: To what extent do individual preferences, perception, ideals and values matter in political society? Or, to quote Kymlicka, "Are good ways of life more likely to establish their greater worth when they are evaluated in the cultural marketplace of civil society, or when the preferability of different ways of life is made a matter of political advocacy and state action?" (Kymlicka, 1997: 219) The significance of this question arises from the fact that most individuals resent this intrusion of ethical and political decisions on their market preferences and consumptive choices. One instant way to confront this question is to reduce it to the problematics of majoritarianism. Majoritarian democracy in a crucial sense interns political injustice in that its mechanism ensures the persistent domination of the minority and individuals with contra-majority opinions. ${ }^{2}$ However, this reduction of the question is unfair. This is because democracy, in its Athenian and liberal mode, cannot escape the stigma of the majority. The fundamental difference between the two consisted in the mechanism for the constitution of the majority. In 
the Athenian democracy, minority and individual contraopinions are incorporated into, not subjected to, the majority consensus. In other words, in Wiredu's graphic statement, the majority would by this consensus thereby "prevail not over, but upon, the minority-it prevails upon them to accept the proposal in question, not just to live with it..." (Wiredu, 1997: 310).

To adequately answer this question, we will initiate a critique of the work of J. S. Mill and Cass Sunstein. As the names of these two theorists reveal, much of the debate about individuals and their preferences in the society has been carried out within the theoretical framework of liberalism. However, to make the debate of relevance to non-liberal governments, we can appeal to the unavoidable coincidence between liberal considerations and democratic discourse. ${ }^{3}$

\section{Human Freedom, Human Preferences and Democratic Politics}

In the ancient period, democratic politics, in Plato's words, is an art "whose business it is to care for souls." This translates into a perfectionist vision which the state has for promoting the quality of life of its citizenry through the encouragement of a conception of the public good. This conception of the vision of a good society is arrived at through the frequent and active participation of its active citizens. The state and the citizens are thus actively committed to the inculcation of a virtuous political behaviour that eschews the promotion of private preferences of each of the individuals. This is Rousseau's conception of the General Will. 
On the other hand, the modern state's concern with souls effected a qualitative shift which, contrary to the Athenian democratic experiment, began with the exaltation of the private preferences of the citizens as the only justifiable platform for the legitimacy of government decisions, legislations and policies. This much is clear from Locke's portrayal of the social contract. Liberal scholars who favour this conception of democratic politics took their departure from the paternalistic implication of a state imposing a general conception of the good on individual's personal, private and subjective conceptions.

Paternalism is the idea, in ethics and politics, that a state or an individual has the right to act, in loco parentis, for another person or group of persons considered to be minors and thus incapable of making such rational decisions. To replace this seemingly odious implication of paternalistic welfarism, liberals opt for what Sunstein refers to as "subjective welfarism." According to him, this idea implies that "...the government, even or perhaps especially in a democracy, should attend to conceptions of welfare as subjectively held by its citizens" (Sunstein, 1994: 293). In this sense, Sunstein argues, certain forms of utilitarianism are variants of subjective welfarism. We are therefore led to J. S. Mill not only as the most brilliant articulator of utilitarianism, but also as the arch-liberal (apart from Locke and Rawls). In On Liberty, the classical statement of his liberal views, Mill expresses his principle of liberty which can be invoked to stay the hands of the society from violating the freedom of the individual. This 
principle is this: “...the sole end for which mankind are warranted, individually or collectively, in interfering with the liberty of action of any of their number, is selfprotection. That the only purpose for which power can be rightfully exercised over any member of a civilised community, against his will, is to prevent harm to others" (Mill, 1961: 263).

Mill was led to this point of acute individualism chiefly by what he sees as the tyranny of the state or society on the flowering of individual potentials. This is because, for him, there exists some realm of individual's life which the society has no right whatsoever in adjudicating over, except the individual himself. On the domineering and paternalistic attitude of the society, he writes:

Society can and does execute its own mandates: and if it issues wrong mandates instead of right, or any mandates at all in things which it ought not to meddle, it practises a social tyranny more formidable than many kinds of political oppression, since, though not usually upheld by such extreme penalties, it leaves fewer means of escape, penetrating much more deeply into the details of life, and enslaving the soul itself. Protection, therefore, against the tyranny of the magistrate is not enough: there needs protection also against the tyranny of the prevailing opinion and feeling; against the tendency of society to impose, by other means than civil penalties, its own ideas and practices as rules of conduct on those who dissent from them; to fetter development, and, if possible, prevent the formation, of any individuality not 
in harmony with its ways, and compel all characters to fashion themselves upon the model of its own (Mill, ibid: 258).

From this principle and the motivation for it, it is easy to infer the kind of society Mill's liberalism permits: A society peopled by individuals as isolated atoms in interstellar relationship. He will therefore be in violent disagreement with Rousseau on the necessity of sometimes forcing individuals to be free. ${ }^{4}$ Here, Mill's utilitarian principle coincides with his political concern: The best yardstick for measuring the good life or the good society lies in whether it is good for the individual constituents; whether, that is, it aggregates to the increment of the totality of human happiness (Lerner, 1961: xxiv). Mill's principle of liberty, we should note, is inextricably caught in the crossfire of the raging debate between liberalism and communitarianism. This debate centers on the question of the compatibility of an individualistic philosophy within the ambit of an ethics of responsibility and civic duties which are relevant for social progress. Crucial to this question is the metaphysical one of what form of society will support the ontological picture of the moral agent as conceived in either the liberal or the communitarian theories.

True to their Millian antecedent, liberals conceive of the human moral agent as an extremely individuated person whose preferences cannot be legislated upon by the society. Such an individual is taken as the fundamental element of any welfare system, and liberty is the only frame of freedom essential for the development and 
fulfillment of its potentials. To achieve freedom, the society must see to it that there exists a "manifold diversity" of experiences and life plans which the individual can choose from to further its own plans. This pluralism, for Mill as well as for other liberals, helps to give scope and direction for the expression "of a large variety in types of character... [and it also gives] full freedom to the human nature to expand itself in innumerable and conflicting direction."

This mechanism of the individual-society relation is contained in the concept of the "unencumbered self": This is the picture of an individual who possesses the normative power of self-determination to meander its way through the plural context of manifold life-projects without being constituted by any of them. Such an individual, that is, is a member of the society, but such a membership is merely cooperative rather than constitutive because it has the capacity to distance itself from any prospective experience and life plans, objectively scrutinise them, make a rational choice, discard them if it discovers they are no longer worthwhile or revise them if they are revisable to fit its subjective conception of the good life worth pursuing. In this wise, for liberals, any attempt by the state to interfere in this process of self-determination in order to impose a particular conception of the common good is antithetical to the welfare of the individual. ${ }^{5}$ Thus, the right to choose or the capacity to be able to rationally revise one's conception of the good is, for liberals, intrinsically more valuable than the conception of the good. This is Mill's liberty principle, and what Rawls 
means by the priority of the right over the good. He elaborates:

As free persons, citizens recognise one another as having the moral power to have a conception of the good. This means that they do not view themselves as inevitably tied to the pursuit of the particular conception of the good and its final ends which they espouse at any given time. Instead, as citizens, they are regarded as, in general, capable of revising and changing this conception on reasonable and rational grounds. Thus it is held to be permissible for citizens to stand apart from conceptions of the good and to survey and assess their various final ends (Rawls, 1980: 544).

This perspective ultimately commits liberals to the principle of state neutrality in the ordering of the market preferences and consumptive choices of individuals. Just like the laissez faire of the capitalistic marketplace, the society becomes a cultural marketplace that operates on the principle of an invisible hand and without the intervention of the state (Cf. Buchanan, 1986: 5, 6).

We can immediately see the value of the liberal argument especially as regards Mill's principle of liberty. This is because we value someone who has the moral strength to stand alone in the society as a selfdefining being. Is it also not a feature of our society that we are free to voluntarily join any association or community that we feel would better serve our purposes in life? As such, it is really doubtful if we can really deny the cooperative basis of our society. However, this does not still tell us how individuals should relate to 
legislations and regulations which seem to be ethically and politically relevant if we are to achieve any vision of a good life worth pursuing. This is where we confront the communitarian rejection of liberal neutrality in the ordering of individual subjective preferences in the matter of welfare policies.

For communitarians, the entire philosophy of liberal ontology of the self together with the neutrality of the state is both dangerous and false. The philosophy is dangerous because such a market ordering of the subjective preferences of the individual, portents a serious threat to the well-being of the society itself. For instance, to take Mill's liberty principle to its logical conclusion, your personal preferences and consumptive choices may be served by your promoting the sale and distribution of fake drugs, impure bottled or packaged water, and other substandard products. However, the fulfillment and expansion of your sphere of freedom would harm many others and limit their range of options to worthwhile preferences. It will also significantly compromise the existence of future generation yet unborn. Thus, the state may have to intervene in this context with regulations and legislations to ensure the survival of the society.

The liberal philosophy, for communitarians, is false because it deliberately undermined the necessity of the cultural context required for the development of individual potentials and capacities. The argument for state neutrality in the ordering of the subjective preferences of the individuals is, they contend, self- 
defeating since any attempt by the state to hands off the operation of the cultural marketplace will inevitably emasculate the cultural framework that supports the pluralism required to achieve self-definition by individuals. This is how Cragg puts it:

Any collective attempt by the liberal state to protect pluralism would itself be in breach of liberal principles of justice. The state is not entitled to interfere in the movement of the cultural marketplace except, of course, to ensure that each individual has a just share of available necessary means to exercise his or her moral powers. The welfare or demise of particular conceptions of the good and, therefore, the welfare or demise of social union of a particular character is not the business of the state (Cragg, in Kymlicka, 1997: 217).

On the other hand, individuals are not only atomistic, lone right-bearing persons revolving in interstellar space. They are sui generis social beings. ${ }^{6}$ This is essentially what Kymlicka terms the "social thesis." It implies that any development of potentials of individuals requires, $a b$ initio, the cultural context of the society. In "Atomism," Charles Taylor contents that rights are human capacity which can only be meaningfully developed within society. To thus assert the primacy of rights not only leads us to the affirmation that it is a human capacity, it must also commit us to the obligation to belong to and sustain the society that helps develop this capacity. This affirmation, for Taylor, leads us further in "accepting certain standards by which a life may be judged full or truncated" (Taylor, 1992: 37). For instance, Crowley 
buttresses this point by insisting that the affirmation of the notion that men in a community of shared experiences and language is the only context in which the individual and society can discover and test their values through the essentially political activities of discussion, criticism, example, and emulation. It is through the existence of organised public spaces, in which men offer and test ideas against one another...that men come to understand a part of who they are (Crowley, in Kymlicka, 1997: 220).

Thus, again, the ordering of the market must bear the intrusion of the state. There is therefore a short step from this social thesis to the idea of state perfectionism espoused by the communitarians. This idea takes its cue from the fact that individuals cannot escape their embedded nature in the society to the conclusion that they must therefore bear, sometimes, the interference with their rights. Sullivan provides the context for the idea of state perfectionism:

[S]elf-fulfillment and even the working out of personal identity and a sense of orientation in the world depend upon a communal enterprise. This shared process is the civic life, and its root is involvement with others: other generations, other sorts of persons whose differences are significant because they contribute to the whole upon which our particular sense of self depends. Thus mutual interdependency is the foundational notion of citizenship... Outside a linguistic community of shared practices, there would be biological homo sapiens as logical abstraction, there could not be human beings. 
This is the meaning of the Greek and medieval dictum that the political community is ontologically prior to the individual. The polis is, literally, that which makes man, as human being, possible (Sullivan, 1982: 158, 173).

State perfectionism assumes that the state, rather than staying aloof of the market ordering of individual preferences and desires, interferes in order to promote a particular conception of the common good. For the communitarians, one should not straightforwardly assume the implication of paternalism here. The fact of the matter, which is very significant, is that people are often mistaken about what the right decisions are that would be beneficial to their pursuance of the good life. In fact, in most cases, most individuals mistake the life they are currently living which they believe to be good for the good life. Yet, for state perfectionists, the interest which is uppermost is living the good life and not the life we currently believe to be good (Kymlicka, 1997: 203). Since it is possible therefore for people to make crucial mistake about their decisions in life (which often times can lead to grievous harms to others), then it would be wicked to leave them alone to their ability for self-determination. The state thus has an obligation to interfere since, for Plato, its business is caring for souls.

The liberal would respond by arguing that such interference, no matter its good intention, is still paternalistic in its restriction of the ability of the individual to self-determine his or her own future and life projects. They would therefore deny that people can actually make mistake in their judgement about the 
value of their preferences and choices. For Kymlicka, "Defenders of self-determination might argue that judgements of value, unlike judgements of fact, are simply the expressions of our subjective likes and dislikes. These choices are ultimately arbitrary, incapable of rational justification or criticism" (1997: 201)

This is the critical juncture in Sunstein's contention against what he calls "subjective welfarism." $\mathrm{He}$ champions what can be referred to as a legal paternalism (but we think without the odious connotation of acting on behalf of minors or taking over their capacity for selfdetermination). His thesis hinges on the differences between the good life proper (if there is anything like that) and what we currently believe to be good. He argues that a democratic government may sometimes legislate for the good of its citizens or mould their own perception of the good life against their expressed preferences. This argument is based on what he terms the endogeneity of certain preferences. Preferences are endogenous if they are not fixed and stable, and their formulation depends on the existence or lack of it, of certain transient factors. On this basis, for Sunstein, we can justify the distinction between the interests of citizens and their subjective preferences. To uphold this thesis, Sunstein claims that the desire of liberals to promote the individual preferences of citizens unwittingly undermine their rabid devotion to the principle of autonomy. In other words, “...subjective welfarism, even as a political conception, is unsupportable by reference to principles of autonomy or 
welfare, the very ideas that are said to give rise to it" (Sunstein, 1994: 293).

This thesis turns on two arguments. First, Sunstein contends that preferences are a function of legal rules and as such, these rules cannot be justified again by reference to the preferences. According to him, "Whether people have a preference for a commodity, a right, or anything is in part a function of whether the government has allocated it to them in the first instance. There is no way to avoid the task of initially allocating an entitlement, and the decision to grant an entitlement to one person frequently make that person value that entitlement than if the right had been allocated to someone else" (ibid). Therefore, the initial allocation of the right or entitlement serves as the basic "reference state" from which the judgment about values, worth and fairness can be made. In this sense, government cannot hope to take subjective preferences as given or as the foundation of political actions.

Two, and flowing from the above, if any preference is to be satisfied, then it would not be the individual's current preferences but only those which are contiguous with the best or highest conception of the good and of human happiness. ${ }^{7}$ However, current preferences are endogenous and not stable. In consequence, therefore, Sunstein argues:

...the satisfaction of private preferences, whatever their content and origins, does not respond to a persuasive conception of liberty or autonomy. The notion of autonomy should refer instead to decisions reached with 
a full and vivid awareness of available opportunities, with reference to all relevant information, and without illegitimate or excessive constraints on the process of preference formation. When these conditions are not met, decisions should be described as unfree or nonautonomous; for this reason, it is most difficult to identify autonomy with preference satisfaction. If preferences are a product of available information, existing consumption patterns, social pressures, and governmental rules, it seems odd to suggest that individual freedom lies exclusively or by definition in preference satisfaction, or that current preferences should, on grounds of autonomy, be treated as the basis for settling political issues (Sunstein, 1994: 294, 295).

Furthermore, however, autonomy provides the basis for government's intervention, especially in the processes of preference formation. These interventions occur through the democratic mechanism of the active participation and deliberation of the citizens in the process of policy formulation that initiate the legislation of the collective aspirations and considered judgments or decisions of the people. This is how collective judgments are able to overwhelm subjective preferences. Collectively, the citizens, through deliberation and reasoning, transform values and perceptions of interests which are often subjectively beclouded in the marketplace. For Sunstein, "On this view, political autonomy can be found in collective self-determination, as citizens decide, not what they 'want,' but instead who they are, what their values are, and what those values require" (ibid). 
Mill, on his own also recognises the significance of a democratic government and its right to formulate certain policies. He will however be hard-pressed to agree with Sunstein's legal paternalism and the idea of a political autonomy formulated within the ambit of state perfectionism. Yet, Mill finds it difficult, in On Liberty, to resolve the friction between the liberty principle and the social character of man.

Consider the concept of trade. Mill is unequivocal about the fundamental character of trade: it is a social act. He claims, for instance, that "Whoever undertakes to sell any description of goods to the public, does what affects the interest of other persons, and of the society in general; and thus his conduct, in principle, come within the jurisdiction of society..."(Mill, 1961: 341). In this context, government is at liberty to legislate and regulate the conduct of such trade. But the pull of the liberty principle is too much, for in the same breath, he contends that such governmental interference infringes on the liberty, not of the seller, but of the buyer to purchase whatever satisfies his preferences and what he considers worthwhile.

\section{Conclusion}

So far in this essay, we have examined arguments, straddling the liberal welfarists' exaltation of the private preferences of individual citizens as the only justifiable ground for actualising the good life and the good society, and the paternalists' imposition of a general (state) conception of the good on individuals' personal and subjective inclinations as the most viable platform 
for achieving same. While agreeing with the subjective welfarists that each individual has his/her own autonomous visions of a good society and good life project, we contended that such autonomy can only be formulated within the ambit of state protectionism and that this provides the basis for government's regulation and intervention in the processes of preference formation. Resolving the controversy between subjective welfarism and communitarian paternalism on the role of the individual and the state, in the quest for the good life and good society, would therefore require more empirical arguments than what both the subjective liberal welfarists and the communitarian paternalists have felt so far disposed to provide (Kymlicka, 1997: 230). Such arguments would settle fundamental questions like whether or not individual subjective preferences are prior to those of the state, whose primary responsibility it is to merely protect them; whether or not a state can carry out such paternalistic intervention and still remain within the ambit of democratic frameworks; and in fact, whether or not such government decisions should be submitted to public debates and deliberations involving individual members of the society. Answers to these questions would no doubt be beyond the purview of this already long paper.

\section{Notes}

1. Policy is derived from Old French policie meaning government or civil organisation; while politics derived from the Greek politeia translated as "civil organisation or the state". It is interesting to note also that the word "police" also have its root from the Greek politeia. 
2. This portrayal of the issue of majoritarianism also raises the problem of why democracy has a moral force; why, for instance, democratic regulations are binding upon me in conscience.

3. The coincidence is unavoidable, not because of an "end of history" or "end of ideology" rhetoric (of Fukuyama and co.), but simply because liberal democratic principles are so globally dispersed that they seem almost self-evident. This is definitely due to the twin factor of globalisation and American armed liberalism that roams the world omnipotently.

4. We should here be reminded of Rousseau's classic statement, at the beginning of his Social Contract: "Man is born free but is everywhere in chains."

5. Liberals and communitarians both have a different attitude to the conception of a "common good." For liberals, the common good is nothing more than the state policy that ensure that there is a process through which individual preferences all have equal weight "not in the sense that there is an agreed measure of intrinsic value or satisfaction with respect to which all these conceptions come out equal, but in the sense that they are not evaluated at all from a [public] standpoint" (Rawls, 1982: 172). The state promotes the common good by staying clear of any attempt to favour a particular conception of that good. On the other hand, the communitarians conceive the common good as a substantive conception of the good life which not only defines the collective way of life of the society but also to which all must be subjected. 
6. This point is not actually in contention between the liberals and the communitarians, except that each interprets the socialness of individuals differently.

7. It is in this sense that the communitarians finds an ally in Aristotle. For him, though

...all associations come into being for the sake of some good-for all men do all their acts with a view for achieving something which is, in their view, a good... [however] the particular association which is the most sovereign of all, and includes all the rest, will pursue this aim most, and will thus be directed to the most sovereign of all goods. This most sovereign and inclusive associations is the city [polis], as it is called, or the political association (Aristotle, 1995: 1252 1 ).

Adeshina Afolayan and Francis Offor are of the Department of Philosophy, University of Ibadan, Nigeria

\section{References}

Aristotle (1995), Politics, trans. by Ernest Barker; revised with an introduction and Notes by R. F. Stalley (Oxford: Oxford University Press).

Aron, Raymond (1978), Politics and History: Selected Essays by Raymond Aron, collected, translated and edited by Miriam Bernheim Conant (New York: The Free Press). 
Buchanan, James, M. (1986), Liberty, Market and the State (Sussex: Harvester Press).

Ekeh, P. P. (1975), "Colonialism and the Two Publics in Africa: A Theoretical Statement," Comparative Studies in Society and History, Vol. 17, No. 1, January.

Fuller, Lon L. (1958), "Positivism and Fidelity to Law", Havard Law Review, Vol. 71.

Hinsley, F. H. (1989), Sovereignty, second edition (Cambridge: Cambridge University Press).

Hobbes, Thomas (1989), cited in Tuck Richard, Hobbes (Oxford: Oxford University Press)

Kymlicka, Will (1997), Contemporary Political Philosophy: An Introduction (Oxford: Clarendon Press).

Lerner, Max (1961), "Introduction" in J. S. Mill, The Essential Works of J. S. Mill (New York: Bantam Books

Locke, John (2002), Two Treatises on Government, cited in The Microsoft Encarta Encyclopedia.

Mill, J. S. (1859, 1961), On Liberty (New York: Bantam Books).

Omoregbe, Joseph I. (1991), "Politics and Morality" in F. A. Adeigbo (ed.), Readings in Social and Political Philosophy, Vol. 1, (Ibadan: Claverianum Press)

Rawls, John (1982), "Social Unity and Primary Goods," in A. Sen and B. Williams (eds.) Utilitarianism and Beyond (Cambridge: Cambridge University Press).

Scott, Charles, E. (1996), On the Advantages and Disadvantages of Ethics and Politics 
(Bloomington and Indianapolis: Indiana University Press).

Shively, Phillips (1997), Power and Choice (New York: McGraw-Hill).

Sullivan, W. (1982), Reconstructing Public Philosophy (Berkeley, Cal.: University of California Press).

Sunstein, Cass, R. (1994), "Preferences and Politics," in Markate Daly (ed.) Communitarianism: A New Public Ethics (Belmont, Cal.: Wadsworth Publishing Co.).

Taylor, Charles (1992), "Atomism," in Shlomo Avineri and Avner de-Shalit (eds.) Communitarianism and Individualism (Oxford: Oxford University Press).

Wiredu, Kwasi (1997), "Democracy and Consensus in African Traditional Politics: A Plea for a Nonparty Polity," in Emmanuel Chukwudi Eze (ed.) Postcolonial African Philosophy: A Critical Reader (Cambridge, Mass.: Blackwell Publishers). 